\title{
A new myxozoan parasite, Myxobolus allami sp. n. (Myxozoa: Myxobolidae) from the intestinal wall of Sparidentex hasta (Valenciennes) in Arabian Gulf
}

\author{
Lamjed Mansour ${ }^{1,2}$, Heba M. Abdel-Haleem ${ }^{3}$, Marwa Atwa ${ }^{4}$, Ahmed B. Darwish $^{5}$, Saleh Al-Quraishy ${ }^{2}$ \\ and Abdel-Azeem S. Abdel-Baki ${ }^{3^{*}(\mathbb{D})}$ \\ ${ }^{1}$ Zoology Department, College of Science, King Saud University, Saudi Arabia, Riyadh, Saudi Arabia; \\ ${ }^{2}$ Laboratory of Biodiversity, Parasitology and Ecology of Aquatic Systems, Department of Biology, Faculty of Sciences of Tunis, \\ University of Tunis El Manar, Tunis, Tunisia; \\ ${ }^{3}$ Zoology Department, Faculty of Science, Beni-Suef University, Beni-Suef, Egypt; \\ ${ }^{4}$ Zoology Department, Faculty of Science, Fayoum University, Egypt; \\ ${ }^{5}$ Zoology Department, Faculty of Science, Suez University, Egypt
}

\begin{abstract}
Myxobolus allami sp. n. is described from the intestinal wall of the silvery black porgy, Sparidentex hasta (Valenciennes), off Saudi Arabian coast of Arabian Gulf. Two of 20 examined fish were found to be infected with irregular-shaped plasmodia 3-8 mm long $\times 2-3 \mathrm{~mm}$ wide. Mature myxospores are subspherical to elliptical in the valvular view and oval in the sutural view, and are 11-13 (12) $\mu \mathrm{m}$ long, 7-8 (7.5) $\mu \mathrm{m}$ wide and 10-12 (10.8) $\mu \mathrm{m}$ thick. Spores have relatively thin valves and mostly $(\sim 72 \%)$ end with short caudal appendages of $\sim 3 \mu \mathrm{m}$ long. The spores also have two polar capsules, which are oval to elliptical and measure 5-7 (5.7) $\mu \mathrm{m}$ in length and 2-3 (2.7) $\mu \mathrm{m}$ in width. Polar filaments are coiled, with three turns. Transmission electron microscopy revealed that caudal appendages originated from the sutural edge at the posterior pole of the myxospore with density similar to that of its valves. The SSU rRNAgene sequence of the present species does not match any available sequences in GenBank. Phylogenetically, this species is sister to Myxobolus khaliji Zhang, Al-Qurausihy et Abdel-Baki, 2014 within a well-supported clade of Myxobolus-Henneguya with species infecting marine fishes. The combination of molecular data and morphological differences between this and other species of Myxobolus Bütschli, 1882 lead us to propose that the present form be established as a new species, M. allami. The present study also provides more evidence for the idea that caudal appendages cannot be reliably used to distinguish the species of the genera Myxobolus and Henneguya Thélohan, 1892.
\end{abstract}

Keywords: Myxosporea, ultrastructure, phylogeny, SSU rDNA, Saudi Arabia

Myxozoans are a diverse group of multicellular spore-forming parasites exhibiting complex life cycles that include two hosts: a vertebrate (predominantly fish and occasionally amphibians, reptiles, birds and mammals) intermediate host and an invertebrate, mostly annelid or bryozoan, definitive host (Holzer et al. 2018). Myxozoans are assigned to about 64 genera but Myxobolus Bütschli, 1882 (Myxobolidae) contains by far the highest number of species that infect a wide range of freshwater fish with a small fraction infecting marine fish (Fiala et al. 2015, Chaudhary et al. 2018).

Species are assigned to genus Myxobolus based largely on the morphology of their spores, mainly the shape and size of the spore and polar capsules, and the presence of ribs, ridges and striations on the spore valves, as well as the number of turns of the polar filament, the presence of a mu- cous envelope and the number of sporoplasms (Lom and Arthur 1989). The presence or absence of caudal appendages on the myxospore is the main character used to differentiate between the genera Myxobolus and Henneguya Thélohan, 1892 (see Lom and Dyková 2006). However, Kent et al. (2001) concluded from their broad phylogenetic analysis of the myxosporeans that the caudal appendages are not in fact a reliable basis upon which to distinguish these genera. More recently, an increasing amount of sequence data supports the paraphyletic nature of Myxobolus, with a number of Henneguya spp. clustering within the Myxobolus clade (e.g., Fiala 2006, Liu et al. 2010, Zhang et al. 2014).

Even though the validity of Henneguya has been questioned, the genus currently has to be retained since the $M y x$ obolus clade contains not only Henneguya spp., but also 
species of the genera Thelohanellus Kudo, 1933, Unicauda Davis, 1944, Hennegoides Lom, Tonguthai et Dyková, 1991, and Cardimyxobolus Ma, Dong et Wang, 1982 (see Liu et al. 2019). In addition, the current lack of sequence data for the type species of these genera means that their potential inclusion in Myxobolus cannot currently be resolved. Accordingly, it is not possible simply to rename all Henneguya as Myxobolus. In addition, several species of Myxobolus and Henneguya have the same species names, which would cause confusion in the taxonomy due to several homonymies if the genus Henneguya is suppressed.

During an ongoing survey of myxosporean parasites in commercially important fish off the Saudi Arabian coast of the Arabian Gulf, we detected plasmodia containing myxospores mostly having caudal appendages $(\sim 72 \%)$ in the intestinal wall of the silvery black porgy Sparidentex hasta (Valenciennes) (synonym Acanthopagrus cuvieri (Day)) which is native to the Arabian Gulf, western Indian Ocean and coasts of India (Yousif et al. 2003). In addition, $S$. hasta is considered as the foremost promising fish species for aquaculture due to its good acclimatisation to spawn in captivity, high growth rate and high market price (Mozanzadeh et al. 2017). In the present study, we used the combination of morphological characters and SSU rRNA gene sequences to describe a new species of Myxobolus and compare it with its congeners, with emphasis on the problem of the presence/absence of caudal appendages in species of Henneguya and Myxobolus.

\section{MATERIALS AND METHODS}

A total of 20 live freshly-caught silvery black porgy, Sparidentex hasta, were collected from a boat landing site in Dammam City in the Arabian Gulf (26.3992N, 49.9843E), Saudi Arabia in March 2018. Necropsy was performed for all specimens and all organs were carefully examined for myxosporean plasmodia. Plasmodia were carefully excised from the host tissue and some were individually ruptured for light microscopic examination. A total of 30 fresh mature myxospores were observed, photographed and measured following Lom and Arthur (1989). The measurements of the myxospores are presented as range (mean \pm standard deviation) in $\mu \mathrm{m}$. Drawings were prepared with the aid of a camera lucida. Some plasmodia and fresh spores were kept in $80 \%$ ethanol for molecular characterisation. To study their ultrastructure, isolated plasmodia were fixed in $3 \%$ glutaraldehyde in a $0.2 \mathrm{M}$ sodium cacodylate buffer at $4{ }^{\circ} \mathrm{C}$ overnight and then washed in the same buffer. Specimens were post-fixed in $2 \% \mathrm{OsO}_{4}$ with the same buffer. Following dehydration, the samples were embedded in pure resin. Semithin sections were stained with toluidine blue for light microscopic examination. Meanwhile, ultrathin sections were double stained with uranyl acetate and lead citrate, before being photographed using a JEOL-JSM-1011 electron microscope at $80 \mathrm{kV}$.

A Qiagen DNeasy Kit (Qiagen, Hilden, Germany) was used to extract genomic DNA from the ethanol-fixed samples, following the manufacturer's protocol. The sequences of the SSU rRNA gene were amplified using the primers MyxF144 and MyxR1944 (Mansour et al. 2013). Polymerase chain reactions (PCRs) were performed as previously described by Folefack et al. (2019). Briefly, $3 \mu 1$ were prepared by combining $0.5 \mathrm{U}$ of iProof ${ }^{\mathrm{TM}} \mathrm{High}-\mathrm{Fi}$ delity DNA polymerase (Bio-Rad, Hercules, CA, USA), 50-100 ng of genomic DNA, $2 \mathrm{mM}$ of dNTPs, $1.5 \mathrm{mM} \mathrm{MgCl}_{2}$ and $1 \mathrm{mM}$ of each primer. PCR amplification entailed an initial denaturation at $95{ }^{\circ} \mathrm{C}$ for $4 \mathrm{~min}$, followed by 35 cycles of the following protocol: $96^{\circ} \mathrm{C}$ for $20 \mathrm{~s}, 56^{\circ} \mathrm{C}$ for $20 \mathrm{~s}$ and $72^{\circ} \mathrm{C} 90 \mathrm{~s}$. The program was ended after a final extension at $72{ }^{\circ} \mathrm{C}$ for 10 minutes. Each reaction was accompanied by a negative control to check for possible DNA contamination. PCR products were purified after treatment with ExoSAP-ITTM (USB, Afymetrix) and sequenced by a commercial company (Macrogen Inc., Seoul, South Korea) adopting the same primers as used in the initial amplification. The obtained sequences were assembled and edited with BioEdit version 7.2.5 (Hall 1999) and then used to query similar sequences through a standard nucleotide-nucleotide BLAST (blastn) (Altschul et al. 1997). The SSU rDNA sequences of 31 species of Myxobolus, six of them having caudal appendages, and 11 species of Henneguya available in GenBank were used for multiple alignments. The sequences of Myxidium lieberkuehnii Bütschli, 1882 and Zschokkella candia Kalatzis, Kokkari et Katharios, 2015 were used as outgroups.

The sequences were aligned in ClustalX 2.1.0.12 software, applying the default parameters (Larkin et al. 2007). Phylogenetic analyses were conducted using both Maximum likelihood (ML) and Bayesian inference (BI) methods. The model used for nucleotide substitution was the General Time Reversible with gamma distributed rates and invariant sites $(G T R+I+G)$, which was estimated using jModelTest 2.1.1 (Darriba et al. 2012). The ML tree was constructed using MEGA version 6 (Tamura et al. 2013) with bootstrap validation based on 1,000 replicates. The BI tree was established using the Mr-Bayes program version v3.2.5 (Ronquist et al. 2012). The Metropolis-Coupled Markov Chain Monte Carlo (MCMC) algorithm running four chains (nchains=4) was used to estimate the posterior probabilities. Trees were sampled every 100 generations (samplefreq=100). The first $25 \%$ of the trees sampled in each Bayesian run were discarded as burn-in to ensure sampling of the chain at stationarity. A total of 12,011 trees were generated per run. The consensus tree was produced after 10,000,000 generations and an average standard deviation of split frequencies of 0.006124 . Genetic distances were estimated using the Kimura 2-parameter model for a total of 1,291 positions and the rate variation among sites was modelled with a gamma distribution (shape parameter $=1$ ).

\section{RESULTS}

Ten \% (2/20) of silvery black porgy, Sparidentex hasta, were found to be infected with myxozoan parasites.

\section{Myxobolus allami sp. $\mathrm{n}$.}

Figs. 1-5

\section{ZooBank number for species:}

urn:Isid:zoobank.org:act:07CAC6BD-100C-41A5-8945-28E0F8A5E0B0

Description of plasmodia: The infection was noticed as creamy whitish plasmodia in the intestinal wall. Examination of semithin sections revealed irregularly-shaped plasmodia in the muscle layer of the intestinal wall, packed with mostly mature myxospores (Fig. 1A, B). These plasmodia were $3-8 \times 2-3 \mathrm{~mm}$ in size, and were limited by a relatively thick fibrous tissue wall which sometimes extended into the interior of the plasmodia to form septa-like 

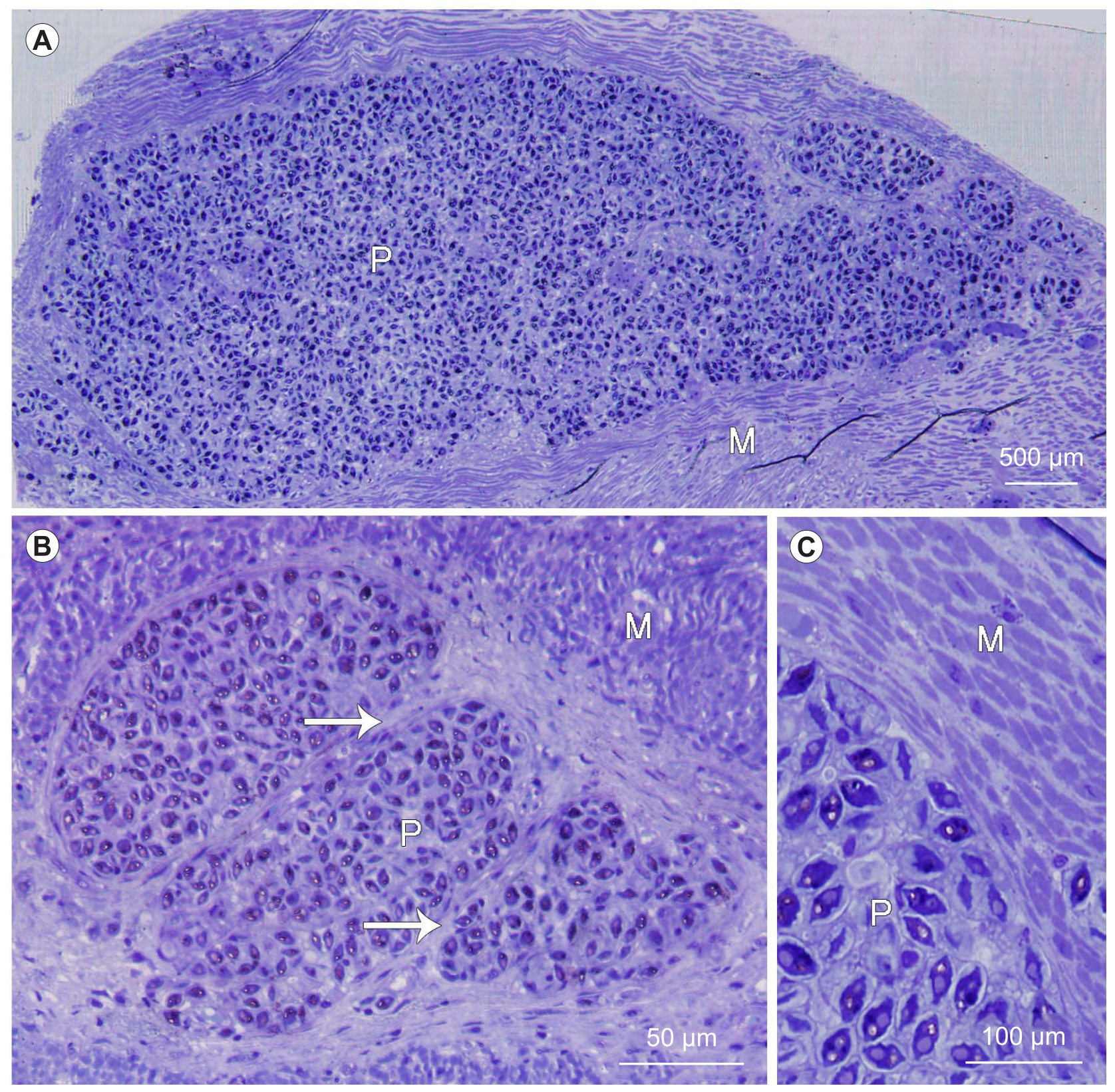

Fig. 1. Photomicrographs of toluidine blue-stained semithin sections of Myxobolus allami sp. $\mathrm{n}$. from the intestine of Sparidentex hasta (Valenciennes). A - irregularly-shaped plasmodium (P) in the muscle of the intestine (M); B - plasmodia surrounded by a relatively thick fibrous tissue wall which extends into the interior of the plasmodia to form septa-like structures (arrows); $\mathbf{C}$ - enlarged part of plasmodium $(\mathrm{P})$ reveals no host reaction around the plasmodium.

structures (Fig. 1B). No host reaction was observed around the plasmodia, apart from the replacement of host muscle by the developing plasmodia (Fig. 1C).

Description of myxospores (in micrometres): mature myxospores (Figs. 2, 3) subspherical to elliptical in valvular view and oval in sutural view, 11-13 (12 \pm 0.6$)$ long, 7-8 (7.5 \pm 0.5$)$ wide and 10-12 (10.8 \pm 0.7$)$ thick. Most spores $(\sim 72 \%)$ with caudal appendages of about 3 long (Figs. 2, $3 \mathrm{~A}, \mathrm{~B})$. Mucous envelope and intercapsular appendix absent while edge markings (4-5) sometimes present (Fig. 2B). Two polar capsules oval to elliptical and mostly equal in size, $5-7(5.7 \pm 0.6)$ long and $2-3(2.7 \pm 0.4)$ wide. Polar filaments coiled with 3 turns (Fig. 3). Sporoplasm single and filled entire space below polar capsules (Figs. 2, 3).
Ultrastructural study revealed two valves consisting of dense outer layer and slightly translucent core surrounding myxospore and joined together at sutural edge (Fig. 4). Caudal appendages originated from sutural edge at posterior pole of myxospore, extending posterolaterally or posterofrontally, equally dense under transmission electron microscopy as valve (Fig. 4B). In younger spores, caudal appendages appeared initially as short extension from valve and then matured to reach their full length (Fig. 4C). Mature polar capsules ovoid with translucent outer zone and dense core containing three polar filament coils (Fig. 4A, B). Sporoplasm binucleated and contains glycogen vacuoles and electron-dense sporoplasmosomes (Fig. 4C, D). 

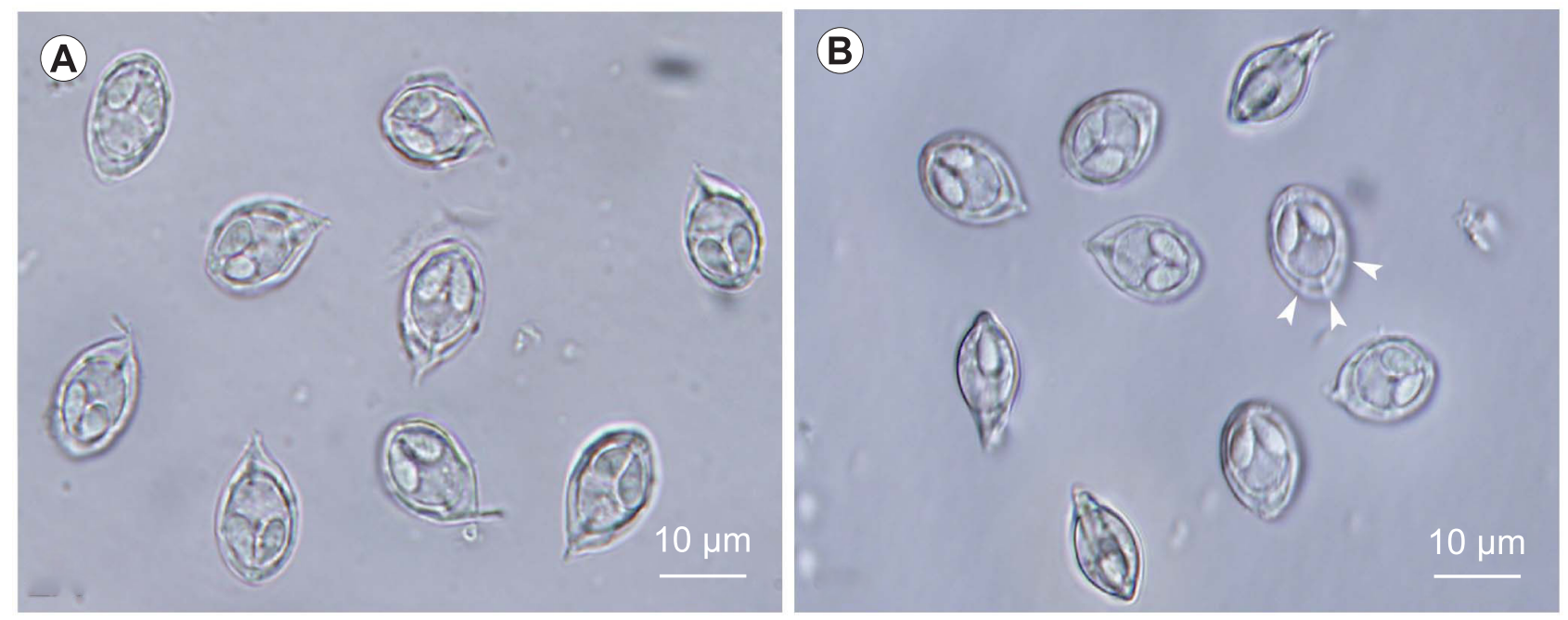

Fig. 2. Photomicrographs of fresh myxospores of Myxobolus allami sp. n. from the intestine of Sparidentex hasta (Valenciennes). A - Myxospores in frontal view; B - Myxospores with edge marking (arrowheads) and some myxospores in lateral view.

A

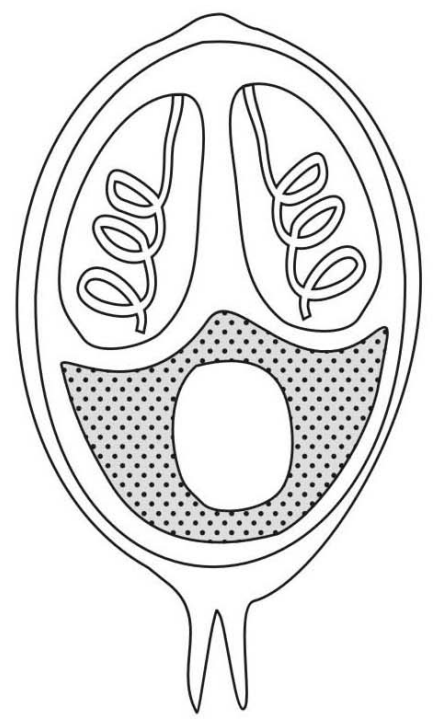

B

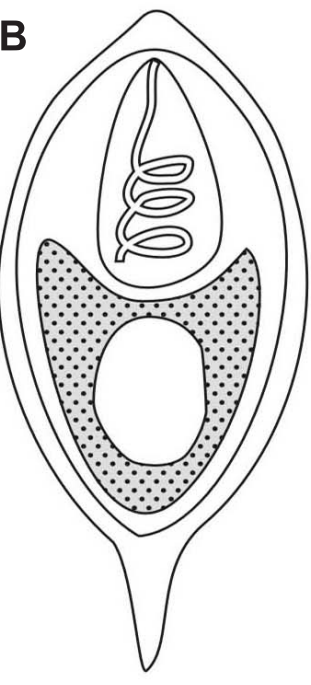

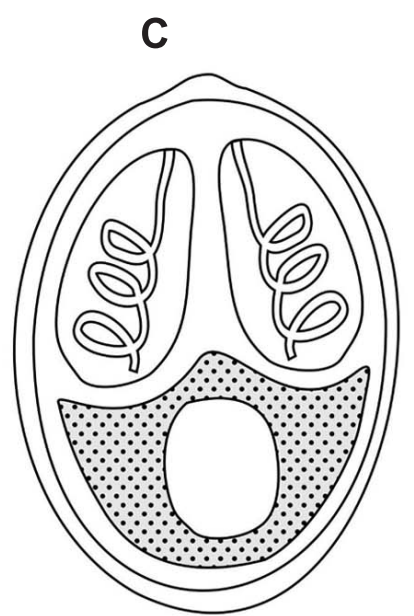

Fig. 3. Diagrammatic line drawings for the mature myxospore of Myxobolus allami sp. $\mathrm{n}$. from the intestine of Sparidentex hasta (Valenciennes). A - frontal view; B - lateral view; $\mathbf{C}$ - myxospore without any caudal appendages.

\section{Taxonomic summary}

Type host: Silvery black porgy, Sparidentex hasta (Valenciennes) (synonym Acanthopagrus cuvieri) (Perciformes: Sparidae).

Type locality: Arabian Gulf at Dammam City (26.3992N, 49.9843E), Saudi Arabia.

Site of infection: Intestinal wall.

Prevalence: $10 \%(2 / 20)$.

Type material: One microscope slide with semithin sections was deposited as syntype in the Museum of the Zoology Department, College of Science, King Saud University, Saudi Arabia, with the number Myxo 01-2020. In addition, the SSU rRNA gene sequence was deposited in GenBank (accession number MW077137).

Etymology: The specific epithet is dedicated to the memory of the late Gamal Allam for his important contribution to the field of immunoparasitology.

\section{Molecular analysis}

Molecular analysis of the newly-studied Myxobolus allowed us to generate a sequence of $1,659 \mathrm{bp}$ of the SSU rRNA gene (accession number MW077137). The G + C content was $47.7 \%$. A BLAST search did not show any identical sequence in the GenBank database. The most closely-related SSU rRNA gene sequence was that of $M y x$ obolus khaliji Zhang, Al-Qurausihy et Abdel-Baki, 2014, which has aberrant spores with small caudal appendages, with a genetic similarity of $95.6 \%$, followed by six species of Henneguya. with distance range between 0.064 and 0.090 (Table 1).

Phylogenetic analysis inferred with ML and BI yielded similar topologies (Fig. 5). Our species clustered with M. khaliji in a well-supported Myxobolus-Henneguya clade that included other species reported from marine ecosystems including M. khaliji, H. yokoyamai Li, Sato, Kamata, Ohnishi et Sugita-Konishi, 2012, H. ogawai, Li, 


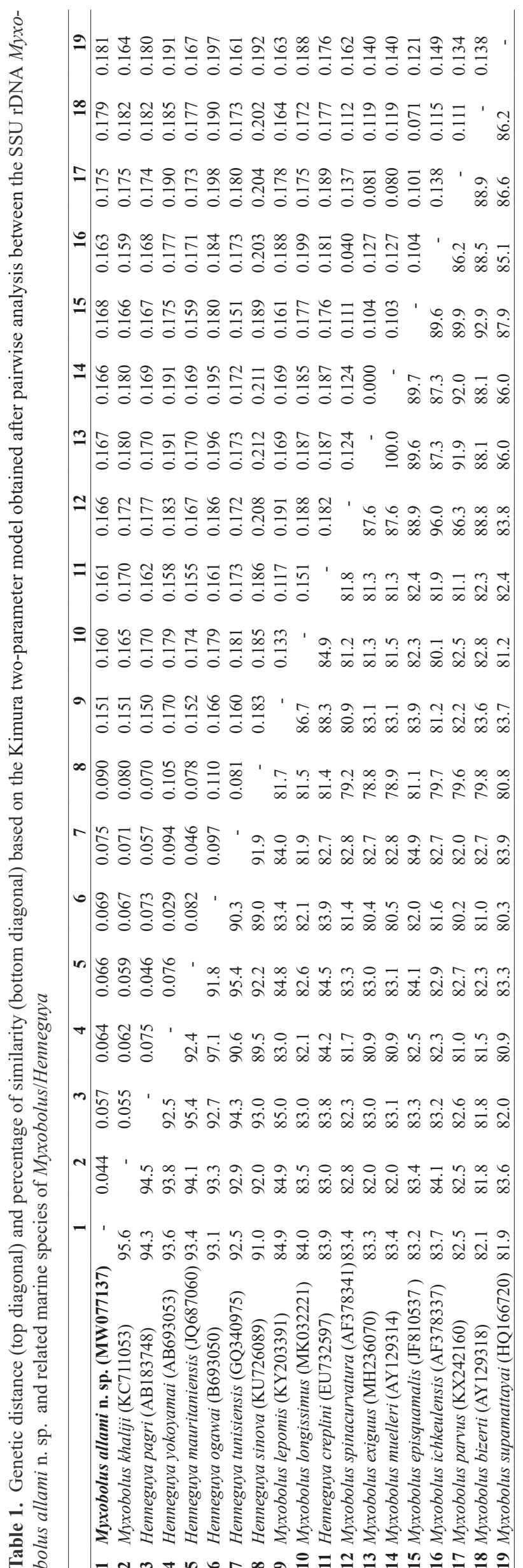

Sato, Kamata, Ohnishi et Sugita-Konishi, 2012, H. mauritaniensis Khlifa, Miller, Adlard, Faye et Sasal, 2012, $H$. tunisiensis Bahri, Marton, Marques et Eszterbauer, 2010, H. sinova Özer, Özkan, Gürkanlı, Yurakhno et Çiftçi, 2016, and $H$. pagri Yokoyama, Itoh et Tanaka, 2005. Among the six species of Myxobolus with caudal appendages selected for this analysis, five clustered together within a Myxobolus/Henneguya clade infecting cyprinid fish.

\section{Remarks}

Two species of Myxobolus have hitherto been described from the Arabian Gulf: M. arabicus Kardousha et El-Tantawy, 2002 from the body cavity of Plectorhinchus schotaf (Forsskål) and M. khaliji from the intestinal wall of Acanthopagrus bifasciatus (Forsskål) (Kardousha and El-Tantawy 2002, Zhang et al. 2014) (Table 2). Myxobolus arabicus differs from our species in having smaller body dimensions, a higher number of polar filament coils (5-7 vs 3), no sutural marking and no caudal appendages. Myxobolus khaliji differs in having smaller spores $(8.1 \times 6.6 \mu \mathrm{m} v s 12$ $\times 7.5 \mu \mathrm{m}$ ) with a thick and prominent caudal end rather than the prominent caudal appendages in the present form. The results of the phylogenetic analysis identified $M$. khal$i j i$ as a species of Myxobolus with the closest phylogenetic relationship to $M$. allami, with the lowest genetic distance of 0.044 .

\section{DISCUSSION}

Myxobolus and Henneguya are myxozoan genera with the highest number of nominal species, representing almost half of the known myxosporean species with about 850 and 200 described taxa, respectively (Eiras and Adriano 2012, Eiras et al. 2014). Traditionally, the presence or absence of two caudal appendages on spores has been the only morphological feature available to assign species to one of these large myxozoan genera (Lom and Dyková 2006). This reliance on the caudal appendages to distinguish between these genera has increasingly been called into question. Fiala et al. (2015) suggested that the appendages on the myxospore surface are functional structures to facilitate better dispersal in the environment, and Eiras et al. (2017) argued that the presence or absence of caudal appendages depends on the parasites' adaptation to different hosts or tissues. Indeed, several studies have recently described species of Myxobolus that showed some percentage of aberrant spores with Henneguya-like caudal projections (El-Mansy 2005, Bahri 2008, Liu et al. 2010, 2013, Zhang et al. 2014). In addition to the above concerns, the comparative analyses of the available SSU rRNA gene sequence data failed to support separation of Henneguya and Myxobolus (see Kent et al. 2001, Fiala 2006, Bartošová et al. 2009, Zhang et al. 2014, Liu et al. 2019). In fact, phylogenetic analyses consistently do not identify a single Henneguya or a single Myxobolus clade but a combined one containing species from both these genera. Species of both genera cluster based on the origin of the host (marine versus freshwater). The tree produced in the present study confirmed this picture from all previous studies because species of Myxobolus and Henneguya cluster together. 

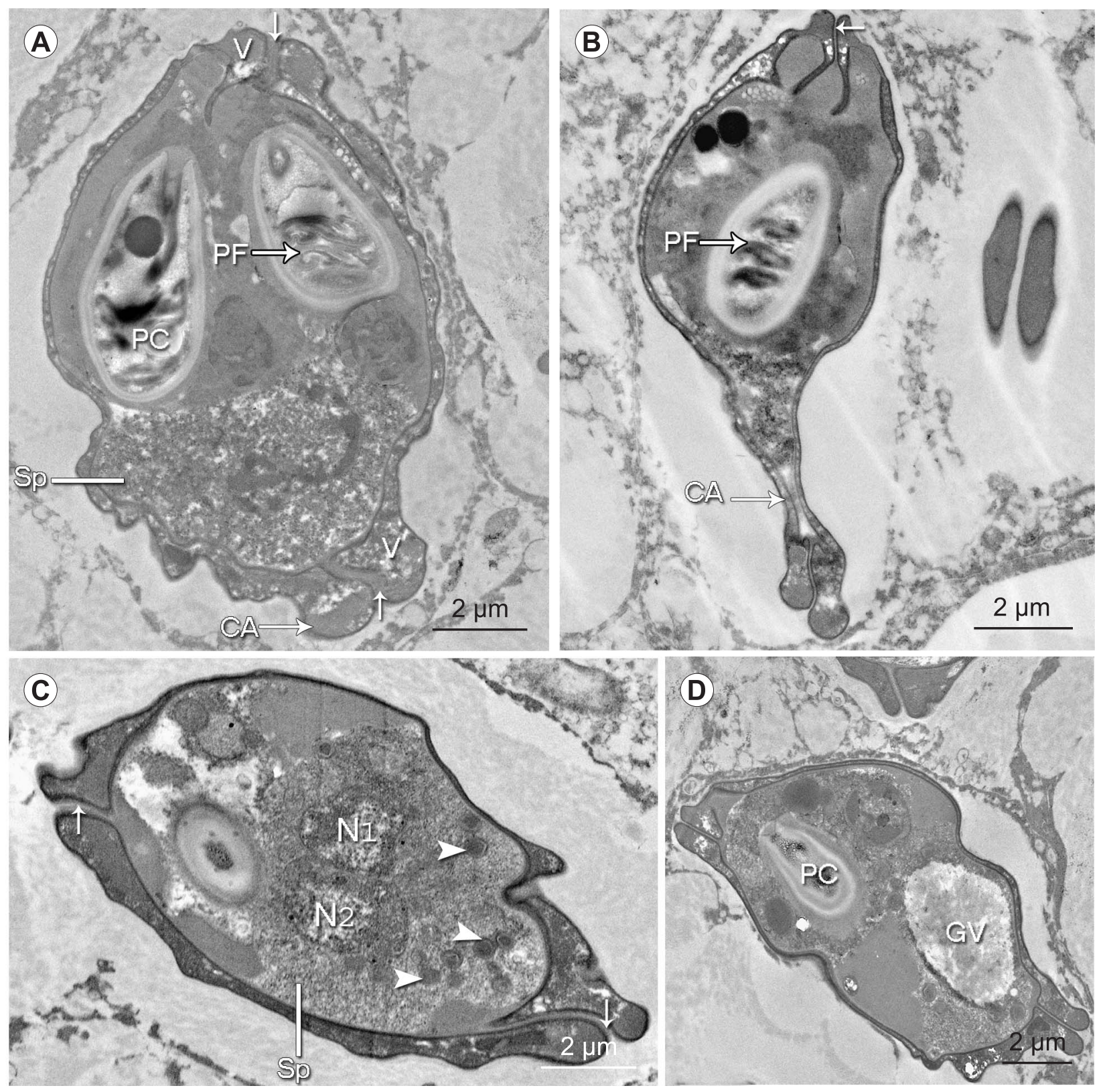

Fig. 4. Transmission electron micrographs of myxospores of Myxobolus allami sp. n. from the intestine of Sparidentex hasta (Valenciennes) showing the myxospore surrounded by two valves (V) met at the suture (arrows) ending with a short caudal appendage (CA) and containing two polar capsules (PC) with polar filament coils (PF). A - myxospore in frontal view; $\mathbf{B}$ - myxospore in lateral view; C - myxospore showing the sporoplasm (SP) with two nuclei (N1, N2) and numerous sporoplasmosomes (arrowheads); D - myxospore showing a large glycogen vacuole (GV).

It is worth noting here that the species of Henneguya most closely related to Myxobolus allami are H. yokoyamai and $H$. ogawai, which are characterised by having relatively short caudal appendages, but which are still quite longer than those of M. allami (10 and 14 vs $3 \mu \mathrm{m}$, respectively). Considering the caudal appendage reported in some species of Myxobolus, only five other species reported to infect cyprinid fishes have been sequenced, in addition to $M$. khaliji (Table 2; Fig. 5). These species are M. tsangwuensis Chen, 1954 from the gills of Cyprinus carpio Linnaeus in China, M. musseliusae Yakovchuk, 1979 from the gills of C. carpio in China, M. wulii Landsberg et Lom, 1991 from the gills of Carassius auratus (Linnaeus) in China, M. tur- pisrotundus Zhang, Wang, Li et Gong, 2010 from lips, skin and fins of C. auratus in China and M. oralis Liu Whipps, Nie et Gu, 2014 from palate of the mouth of $C$. auratus in China (Liu et al. 2010, 2013, 2014, 2019, Zhang et al. 2010, Khlifa et al. 2012; Li et al. 2012). Myxobolus tsangwuensis differed in having an intercapsular appendix and unequal polar capsules with higher number of polar filament coils (5-7 vs 3). Myxobolus musseliusae differs in having wider spores with a mucous envelope and distinct intercapsular appendix and unequal polar capsules with higher number of filament coils (5-6 vs 3). Myxobolus wulii Landsberg et Lom, 1991 can be distinguished from the new species in having quite larger spores with higher number of fila- 


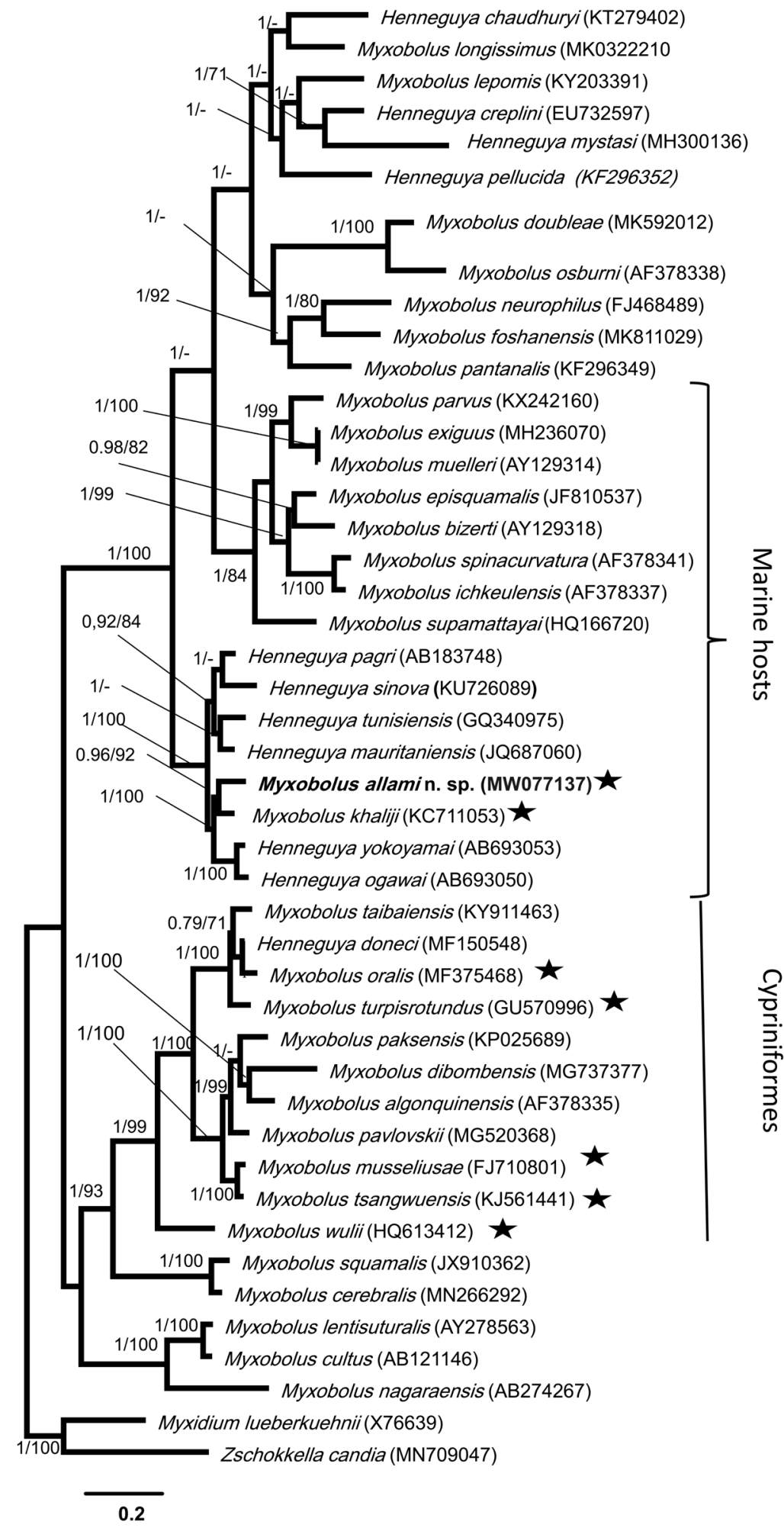

Fig. 5. Phylogenetic tree resulting from Bayesian analysis inferred from the SSU rDNA dataset showing the position of Myxobolus allami sp. n. (in bold). Support values at branching points are listed as posterior probabilities from Bayesian analysis/bootstrap values from Maximum likelihood. Values below $0.7 / 70 \%$ or not supported nodes are indicated by dashes. GenBank accession numbers follow each taxon. Species of Myxobolus Bütschli, 1882 that possess short caudal appendages are indicated with asterisk.

ment coils (7-9 vs 3) whereas M. turpisrotundus in having typically rounded spores with a remarkable intercapsular process and higher number of filament coils (5-6 vs 3). Myxobolus oralis differs in having an intercapsular appendix with higher number of polar filament coils (5-6 vs 3).
These species are genetically distant to M. allami and they cluster together in a Henneguya/Myxobolus clade, all infecting cyprinid fish.

According to the available literature, no myxosporean infection has previously been recorded in the present fish host. 
Thus, in light of the unique morphological and molecular features of the present myxosporean as discussed above, we propose to establish it as a new species, M. allami.
Acknowledgements. This work was supported by Researcher Supporting Project (RSP-2020/3), King Saud University.

\section{REFERENCES}

BAHRI S. 2008: Abnormal forms of Myxobolus bizerti and Myxobolus mülleri (Myxosporea: Bivalvulida) spores with caudal appendages. Bull. Eur. Assoc. Fish. Pathol. 28: 252-255.

Bartošová P., Fiala I., Hypša V. 2009: Concatenated SSU and LSU rDNA data confirm the main evolutionary trends within myxosporeans (Myxozoa: Myxosporea) and provide an effective tool for their molecular phylogenetics. Mol. Phylogenet. Evol. 53: 81-93.

Chaudhary A., Goswami U., Gupta A., Cech G., Singh H., Molnár K., Székely C., Sharma B. 2018: Morphological, histological, and molecular description of Myxobolus ompok $\mathrm{n}$. sp. (Myxosporea: Myxobolidae), a kidney myxozoan from Pabdah catfish Ompok pabda (Hamilton, 1822) (Siluriformes: Siluridae) in India. Parasitol. Res. 117: 1899-1905.

Eiras J.C., Adriano E.A. 2012: A checklist of new species of Henneguya Thélohan, 1892 (Myxozoa: Myxosporea, Myxobolidae) described between 2002 and 2012. Syst. Parasitol. 83: 95-104.

Eiras J.C., Cruz M., Cruz C., Saraiva A., Adriano E.A., Székely C., Molnár K. 2017: Observations on non-random distribution of spores of Henneguya spp. (Cnidaria: Myxosporea: Myxobolidae) within plasmodia. Folia Parasitol. 64: 019.

Eiras J.C., Zhang J., Molnár K. 2014: Synopsis of the species of Myxobolus Bütschli, 1882 (Myxozoa: Myxosporea, Myxobolidae) described between 2005 and 2013. Syst. Parasitol. 88: $11-36$.

El-Mansy A. 2005: Revision of Myxobolus heterosporus Baker, 1963 (syn. Myxosoma heterospora) (Myxozoa: Myxosporea) in African records. Dis. Aquat. Org. 63: 205-214.

FialA I. 2006: The phylogeny of Myxosporea (Myxozoa) based on small subunit ribosomal RNA gene analysis. Int. J. Parasitol. 36: $1521-1534$.

Fiala, I., Bartošová-Sojková, P., Okamura, B., Hartikainen, H. 2015: Adaptive radiation and evolution within the Myxozoa. In: B. Okamura, A. Gruhl and J.L. Bartholomew (Eds.), Myxozoan Evolution, Ecology and Development. Springer, Cham, pp. 69-84.

Hall T.A. 1999: BioEdit: a user-friendly biological sequence alignment editor and analysis program for Window 95/98/NT. Nucleic Acids Symp. Ser. 41: 95-98.

Holzer A.S., Bartošová-Sojková P., Born-Torrijos A., Lövy A., Hartigan A., Fiala I. 2018: The joint evolution of the Myxozoa and their alternate hosts: a cnidarian recipe for success and vast biodiversity. Mol. Ecol. 27: 1651-1666.

Kardousha M., El-Tantawy S. 2002: First record of microsporeans and myxosporeans (Protozoa) infecting some Arabian Gulf fish off the coasts of the Emirates and Qatar with description of Myxobolus arabicus n. sp. Arab Gulf J. Sci. Res. 20: 18-24.

Kent M.L., Andree K.B., Bartholomew J.L., El-Matbouli M., Desser S.S., Devlin R.H., Feist S.W., Hedrick R.P., Hoffmann R.W., Khattra J., Hallett S.L., Lester R. J.G., Longshaw M., Palenzeula O., Siddall M.E., Xiao C. 2001: Recent advances in our knowledge of the Myxozoa. J. Eukaryot. Microbiol. 48: 395-413.
Khlifa S., Miller T.L., Adlard R.D., Faye N., Sasal P. 2012. Henneguya mauritaniensis n. sp. (Myxozoa) from the arterial bulb of Pagrus caeruleostictus (Valenciennes, 1830) off Mauritania. Parasitol Res. 111: 1287-1294.

Larkin M.A., Blackshields G., Brown N.P., Chenna R., McGettigan P.A., McWilliam H., Valentin F., Wallace I.M., Wilm A., Lopez R., Thompson J.D., Gibson T.J., HigGINs D.G. 2007: Clustal W and Clustal X version 2.0. Bioinformatics 23: 2947-2948.

Li Y.C., Sato H., Kamata Y., Ohnishi T., Sugita-Konishi Y. 2012: Three novel myxobolid species of genera Henneguya and Myxobolus (Myxosporea: Bivalvulida) from marine fish in Japan. Parasitol. Res. 111: 819-826.

Liu Y., Lövy A., Gu Z., Fiala I. 2019: Phylogeny of Myxobolidae (Myxozoa) and the evolution of myxospore appendages in the Myxobolus clade. Int. J. Parasitol. 49: 523-530.

Liu Y., Whipps C.M., Gu Z.M., Huang M.J., He C., Yang H.L., Molnár K. 2013: Myxobolus musseliusae (Myxozoa: Myxobolidae) from the gills of common carp Cyprinus carpio and revision of Myxobolus dispar recorded in China. Parasitol. Res. 112: 289-296.

Liu Y., Whipps C.M., Gu Z.M., Zeng L.B. 2010: Myxobolus turpisrotundus (Myxosporea: Bivalvulida) spores with caudal appendages: investigating the validity of the genus Henneguya with morphological and molecular evidence. Parasitol. Res. 107: 699-706.

LiU Y., Whipps C.M., Nie P., Gu Z. 2014: Myxobolus oralis sp. n. (Myxosporea: Bivalvulida) infecting the palate in the mouth of gibel carp Carassius auratus gibelio (Cypriniformes: Cyprinidae). Folia Parasitol. 61: 505-511.

Lom J., ARThur J.R. 1989: A guideline for the preparation of species descriptions in Myxosporea. J. Fish Dis. 12: 151-156.

Loм J., Dyкové I. 2006: Myxozoan genera: definition and notes on taxonomy, life cycle terminology and pathogenic species. Folia Parasitol. 53: 1-36.

Mozanzadeh M.T., Marammazi J.G., Yaghoubi M., Agh N., Pagheh E., Gisbert E. 2017: Macronutrient requirements of silvery-black porgy (Sparidentex hasta): a comparison with other farmed sparid species. Fishes 2: 5.

Yousif O.M., Ali A.A., Kumar K.K. 2003: Spawning and hatching performance of the silvery black porgy Sparidentex hasta under hypersaline conditions. NAGA, World Fish Center Quarterly 26: $13-15$.

Zhang J.Y., Al-Quraishy S., Abdel-Baki A.S. 2014: The morphological and molecular characterization of Myxobolus khaliji n. sp. (Myxozoa: Myxosporea) from the double bar seabream Acanthopagrus bifasciatus (Forsskål, 1775) in the Arabian Gulf, Saudi Arabia. Parasitol. Res. 113: 2177-2183.

Zhang J.Y., Yokoyama H., Wang J.G., Li A.H., Gong X.N., Ryu-Hasegawa A., Iwashita M., Ogawa K. 2010: Utilization of tissue habitats by Myxobolus wulii Landsberg \& Lom, 1991 in different carp hosts and disease resistance in allogynogenetic gibel carp: redescription of M. wulii from China and Japan. J. Fish Dis. 33: 57-68.

Cite this article as: Mansour L., Abdel-Haleem H.M., Atwa M., Darwish A.B., Al-Quraishy S., Abdel-Baki 2021 A.-A.S.: A new myxozoan parasite, Myxobolus allami sp. n. (Myxozoa: Myxobolidae) from the intestinal wall of Sparidentex hasta (Valenciennes) in Arabian Gulf. Folia Parasitol. 68: 017. 